\title{
RESTRUCTURING MODELS FOR ROAD TRAFFIC INSPECTIONS IN THE REPUBLIC OF CROATIA
}

\author{
Saša Šolman, Gordana Štefančić, Marko Slavulj
}

Preliminary communication

The scope of activities of Road traffic inspection in Croatia was increased significantly by the accession to the European Union, primarily due to control of application of social legislation in road transport that regulates working time of mobile workers, the area of the tachographs and tachograph workshops and issuing of memory cards for drivers, service technicians and transporters. The question is whether the Road traffic inspection in the Republic of Croatia is organized in the right way and whether the existing organization and the functioning can fulfil all the set tasks. Therefore, this paper proposes application of scientific methods for analysing of models for possible restructuring of Road traffic inspection in the Republic of Croatia, advantages and disadvantages of the proposed models and the possibility of further improvement of this service.

Keywords: models of restructuring; monitoring of road transport; road safety; road traffic inspection

\section{Modeli preustroja inspekcije cestovnog prometa u Republici Hrvatskoj}

Prethodno priopćenje Opseg aktivnosti Inspekcije cestovnog prometa u Hrvatskoj je s ulaskom u Europsku Uniju znatno povećan, prvenstveno zbog nadzora primjene socijalnog zakonodavstva u cestovnom prijevozu koje regulira područje radnih vremena mobilnih radnika, područje tahografa i tahografskih radionica te izdavanje memorijskih kartica za vozače, servisere i prijevoznike. Nameće se pitanje da li je Inspekcija cestovnog prometa u Republici Hrvatskoj ustrojena na pravi način te da li se postojećom organizacijom i načinom funkcioniranja mogu ispuniti sve postavljene zadaće. Stoga se u ovom radu primjenom znanstvenih metoda predlažu i analiziraju modeli mogućeg preustroja Inspekcije cestovnog prometa u Republici Hrvatskoj, prednosti i nedostaci predloženih modela te mogućnosti daljnjeg poboljšanja rada ove službe.

Ključne riječi: inspekcija cestovnog prometa; modeli preustroja; nadzor cestovnog prijevoza; sigurnost cestovnog prometa

\section{Introduction}

The purpose and objective of this paper is to explore the role and place of road traffic inspection in implementation of control applications regulations, directives and local regulations governing the commercial road transport in the new circumstances of Croatian membership in the European Union. The research was conducted based on the analysis of current inspection services organizational structure strengths and weaknesses. The paper defines the basic hypothesis according to which possible models of reorganization of road inspection traffic in Croatia are considered, with a view of better effectiveness and action in the future. Previous experiences of other member countries that Croatia intensively cooperates with and the results of SWOT analysis were taken into account.

Table 1 SWOT analysis of Road traffic inspection in the Republic of Croatia (Source: Authors, based on the results of their own research)

\begin{tabular}{|c|c|}
\hline STRENGTHS & WEAKNESSES \\
\hline 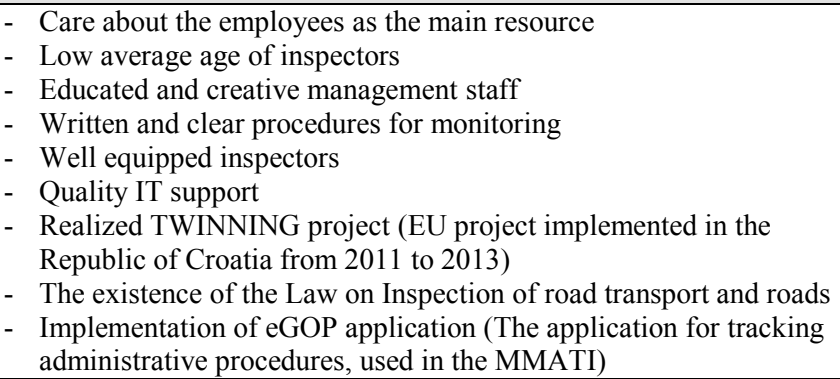 & 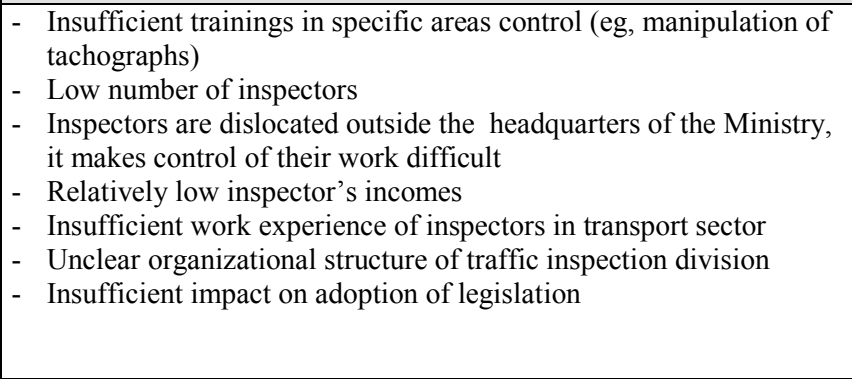 \\
\hline OPPORTUNITIES & THREATS \\
\hline $\begin{array}{l}\text { - Possibility of extension of responsibility and areas of supervision } \\
\text { New organization of the Ministry of maritime affairs, transport and } \\
\text { infrastructure } \\
\text { - Possibility of additional education through membership in ECR } \\
\text { (Euro Controle Route - Association of road traffic inspections of } \\
\text { the European Union) and CORTE (Politically independent and } \\
\text { expert advisory body of the European Commission for road } \\
\text { transport) } \\
\text { - Possibility of international cooperation with other EU Member } \\
\text { States } \\
\text { - Possibility of financing future projects from EU funds } \\
\text { - Possibility of further development of software CRIS (Croatia Road } \\
\text { Inspection System - applications for monitoring and support to } \\
\text { working activities of road traffic inspectors in the Republic of } \\
\text { Croatia) }\end{array}$ & 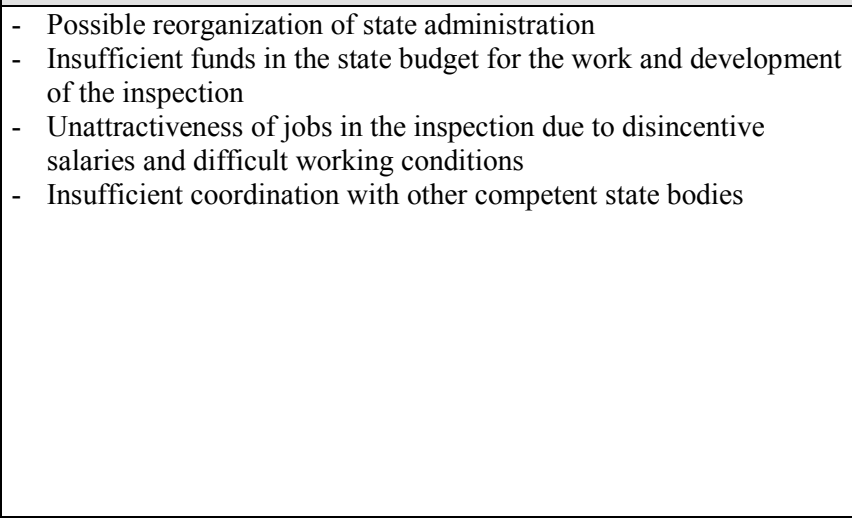 \\
\hline
\end{tabular}




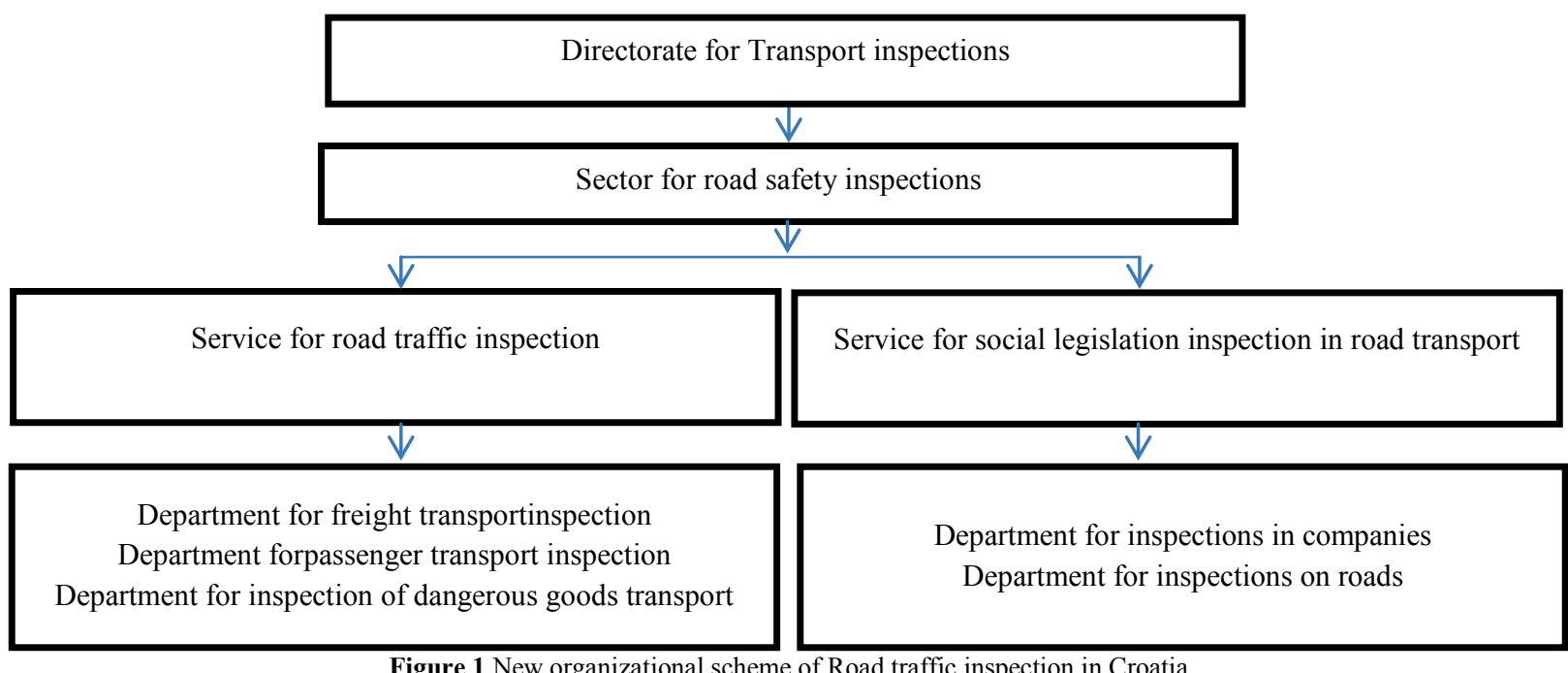

Figure 1 New organizational scheme of Road traffic inspection in Croatia

\section{SWOT analysis for Road traffic inspection in the Republic of Croatia}

In order to analyze current situation of organization and functioning of the Road traffic inspection in Croatia, SWOT analysis is shown in Tab. 1.

\section{Organizational structure of Road traffic inspection in the Republic of Croatia}

For the purposes of planned restructuring of Ministry of maritime affairs, transport and infrastructure, a proposal for a new organizational scheme of Road traffic inspection was made (Fig. 1), which is given below. Its adoption and operationalization are expected during the month of June 2015.

The new organizational chart gives additional significance to increase road safety by Road traffic inspection and by Services for social legislation inspection in road transport, and in accordance with guidelines of the European transport policy. Due to heavy goods vehicles in Croatia taking part in relatively small percentage in traffic accidents with severe consequences, here primarily we can talk about suppression of making extra profit of carriers through overwork of drivers and contribution to maintaining of health and preventing occurrence of occupational diseases.

The new organizational chart of Road traffic inspection, as well as the current state shown in the SWOT analysis, imposes the need for proposals in the form of the model which will determine necessary number of inspectors and reorganization models for Road traffic inspection in Croatia.

\section{EU and international comparison of road traffic inspection organizational structure}

Tab. 2 gives an overview of the state inspection of road traffic in Slovenia, Hungary, Poland, Germany and Montenegro, in a way where for each of those countries the Croatian model of possible restructuring or its elements can somewhere be found, or where their inspection has characteristics of Croatian models. Following reasons for the selection of these countries are: Slovenia (SLO) is neighbor Member State with whom RH inspection regularly undertakes joint bilateral surveillance activities of road transport in the field of transport and of social legislation according to European directives. It is the same case with Hungary (H). Poland (PL) and Germany (D) were selected because they were Croatian junior and senior partners during the implementation of the twinning programs in the framework of the IPA project to adapt the business of road traffic inspection in the Republic of Croatia with the acquis and EU practices. Program and project were conducted during the negotiations for membership in the EU. Neighboring Montenegro (MNE) was selected because it is the only non-member state of the European Union, with which the Croatian road traffic inspectors plan and actively cooperate in the implementation of the road traffic inspections, especially in the border region, with emphasis on the international line and occasional transport of passengers.

Table 2 Comparison of road traffic inspection organizational structure in different countries (Source: Authors, based on the results of their own

\begin{tabular}{|l|c|c|c|c|c|c|}
\multicolumn{1}{|c|}{ research) } \\
\hline $\begin{array}{l}\text { Organization } \\
\text { through } \\
\text { administration, } \\
\text { sectors and } \\
\text { departments }\end{array}$ & HR & SLO & H & PL & D & MNE \\
\hline Specialization & & & & $\#$ & $\#$ & \\
\hline Regionalization & & $\#$ & $\#$ & $\#$ & $\#$ & \\
\hline Work from home & & & & & & $\#$ \\
\hline Marginalization & & $\#$ & & & & $\#$ \\
\hline $\begin{array}{l}\text { Agency for } \\
\text { inspection } \\
\text { activities in road } \\
\text { transport }\end{array}$ & & & & & & \\
\hline
\end{tabular}

\section{Models for reorganization of Road traffic inspection in the Republic of Croatia}

Below are proposed the following reorganization models for Road traffic inspection in the Republic of Croatia:

a) The model of specialization

b) The model of regionalization

c) The model of "work from home" 
d) The model of marginalization

e) The model of Agency for inspection activities in road transport.

\subsection{The model of specialization}

In discussions how to increase the efficiency of Road traffic inspection, one of permanent principles is the principle of specialization of inspectors by the areas of control. In this regard, so far, almost nothing has been done. So, in practice, "the inspectors are doing everything". Applying the model of specialization would enable increased quality control, acquiring of new knowledge and skills, and possibility that inspectors, with the modification of certain regulations [1], educate companies and employees that participate in transport sector, in order to increase their awareness of the need to comply with regulations and reduce the number of committed offenses.

Below are developed mathematical models of required number of inspectors for inspection:

1) freight transport

2) passenger transport

3) dangerous goods transport

4) inspections in companies

5) total number of inspectors.

To define the mathematical models it is necessary to calculate the coefficient of utilization [2] of inspector's working time (Eq. (1)).

$\eta_{\mathrm{r}}=\eta_{\mathrm{r} 1} \cdot \eta_{\mathrm{r} 2} \cdot \eta_{\mathrm{r} 3} \cdot \eta_{\mathrm{r} 4}$

where:

$\eta_{\mathrm{r} 1}$ - coefficient of utilization which includes losses due to vacation (min. 30 - max. 35 days)

$\eta_{\mathrm{r} 2}$ - coefficient of utilization which includes losses due to sick leave (min. 15 - max. 24 days)

$\eta_{\mathrm{r} 3}$ - coefficient of utilization which includes losses due to absence (min. 3 - max. 5 days)

$\eta_{\mathrm{r} 4}$ - coefficient of utilization which includes other loses (min. 5 - max. 15 days).

Considering that it is necessary to do 25 inspections of freight transport, passenger transport and transport of dangerous goods in a month, here are the coefficients of daily number of inspections $B_{\mathrm{IDt}}, B_{\mathrm{IDp}}$ and $B_{\mathrm{IDot}}$ worth 0.83. The sum of work hours $\Sigma H_{\mathrm{r}}$ is calculated on the basis of calendar days during one year multiplied by an eight-hour daily working time.

\section{1) The required number of inspectors in the} department for freight transport inspection

$I_{N \mathrm{t}}=\frac{\Sigma H_{\mathrm{r}}}{\eta_{\mathrm{r}} \cdot B_{\mathrm{IDt}}}$,

where:

$I_{N \mathrm{t}}$ - required number of inspectors for freight transport

$\Sigma H_{\mathrm{r}}$ - number of working hours

$\eta_{\mathrm{r}}$ - coefficient of utilization of inspector working time $(0.82)$
$B_{\mathrm{IDt}}$ - number of daily inspections for freight transport (0.83).

For inspection in one year it is calculated (according to Eq. (2)) that 12 inspectors are needed to carry out inspections in the department for freight transport inspection.

2) The required number of inspectors in the department for passenger transport inspection

$$
I_{N \mathrm{p}}=\frac{\Sigma H_{\mathrm{r}}}{\eta_{\mathrm{r}} \cdot B_{\mathrm{IDp}}},
$$

where:

$I_{N \mathrm{p}}$ - required number of inspectors for passenger transport $\Sigma H_{\mathrm{r}}$ - number of working hours

$\eta_{\mathrm{r}}$ - coefficient of utilization of inspector working time $(0.82)$

$B_{\text {IDp }}$ - number of daily inspections for freight transport (0.83).

For inspection in one year it is calculated (according to Eq. (3)) that 12 inspectors are needed to carry out inspections in the department for passenger transport inspection.

3) The required number of inspectors in the department for inspection of dangerous goods transport

$I_{N \mathrm{ot}}=\frac{\Sigma H_{\mathrm{r}}}{\eta_{\mathrm{r}} \cdot B_{\mathrm{IDot}}}$,

where:

$I_{N \text { ot }}$ - required number of inspectors for dangerous goods transport

$\Sigma H_{\mathrm{r}}$ - number of working hours

$\eta_{\mathrm{r}}$ - coefficient of utilization of inspector working time $(0.82)$

$B_{\text {IDot }}$ - number of daily inspections for dangerous goods transport (0.83).

For inspection in one year it is calculated (according to Eq. (4)) that 12 inspectors are needed to carry out inspections in the department for dangerous goods transport inspection.

\section{4) The required number of inspectors for inspections} in companies

$I_{\mathrm{tv}}=\frac{N_{I_{\text {min }}}}{t_{\mathrm{g}} \cdot B_{\mathrm{IT}}}$,

where:

$I_{\mathrm{tv}}$ - required number of inspectors for companies

$N_{I_{\text {min }}}$ - minimum number of inspections per year (700 companies)

$t_{\mathrm{g}}$ - number of working weeks in a year (adopted time coverage of 42 weeks) 
$B_{\text {IT }}$ - number of inspections carried out weekly (one per week)

$B_{\mathrm{tv}}$ - number of registered transportation companies (3500 during 2014/2015).

$N_{I_{\min }}=0,2 \cdot B_{\mathrm{tv}}$.

For inspection in one year it is calculated (according to Eqs. (5) and (6)) that 17 inspectors are needed to carry out inspections in the department for inspections in companies.

\section{5) The total number of inspectors}

$$
\begin{aligned}
& I_{N_{\text {tot }}}=I_{N_{\mathrm{p}}}+I_{N_{\mathrm{t}}}+I_{N_{\mathrm{ot}}}+I_{N_{\mathrm{tv}}}, \\
& I_{N_{\text {tot }}}=12+12+12+17=53 \text { inspectors } .
\end{aligned}
$$

According to the presented mathematical models it is calculated that the road traffic inspection in the Republic of Croatia takes 53 inspectors (Eqs. (7) and (8)).

According to the author, specialization of inspectors is necessary, primarily due to a very broad and heterogeneous areas of control in road traffic, as well as many regulations that must be learned and specific skills that must be adopted in every segment of work (Fig. 2).

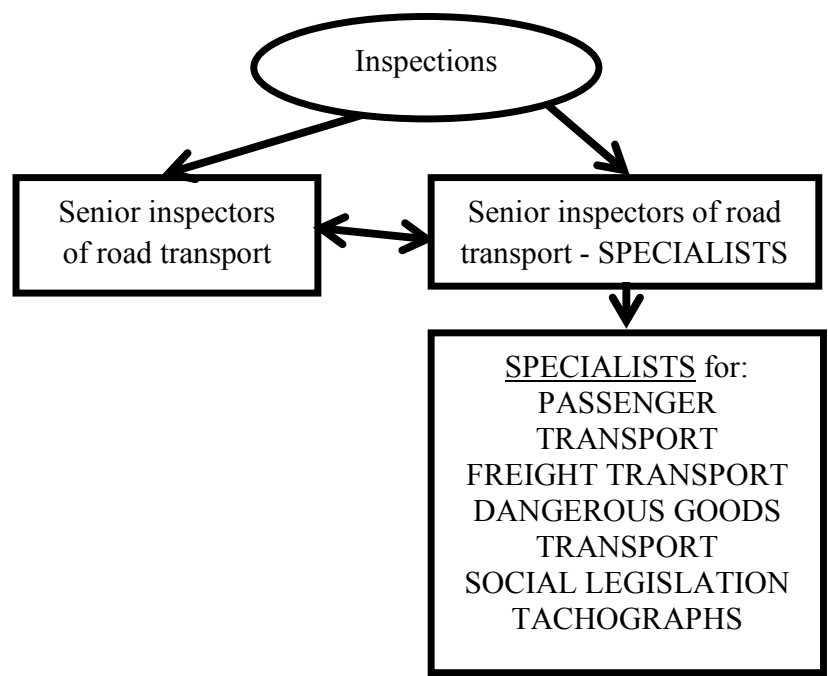

Figure 2 The model of specialization for road traffic inspection

\subsection{The model of regionalization}

As one of the models for reorganization of road traffic inspection in Croatia, a model of regionalization is proposed (Fig. 3).

Under this model, organization of the inspection by departments would be replaced by regional centers, each of them would have own manager, directly responsible to the Head of service at the headquarters of the Ministry.

According to this model, road traffic inspections in each regional centre would be managed by the head of regional centre in the capital of each region. Such a model would greatly facilitate work of the inspection for the following reasons:

a) easier delivery of petitions by companies and individuals and easier communication between public and the inspection at regional level b) easier control of inspectors and their effectiveness and efficiency by the head of a region

c) easier planning of activities for the inspectors, depending on specifics of transport market in a region

d) clear division of powers and responsibilities within the service for road traffic inspection

e) clear responsibility for results by the head of a region

f) clear communication between all members of the service

g) easier keeping of records and work reports

h) easier co-operation with other government bodies at regional level

i) easier implementation of international cooperation

j) easier care for resources and equipment.

\begin{tabular}{|c|}
\hline Service for road traffic inspection \\
\hline REGIONAL CENTRES FOR ROAD TRAFFIC \\
INSPECTION in: \\
Central Croatia - Zagreb \\
Northwestern Croatia - Varaždin \\
Eastern Croatia - Osijek \\
North Adriatic and Lika - Rijeka \\
Central and southern Adriatic - Split
\end{tabular}

Figure 3 The model of regionalization for road traffic inspection in Croatia

\subsection{The model of road traffic inspectors "working from home"}

If we take into account the fact that all the inspectors are connected by IT solutions and connected with headquarters of the Ministry by applications of CRIS and eGOP, one of the models of reorganization for road traffic inspection in Croatia is the "work from home".

This method of performing tasks allows flexible working hours, greater relaxation in performing administrative duties due to "domestic" atmosphere, reducing the cost of employees travelling to and from work, etc.

As a kind of "case study" experience of road transport inspections in the Netherlands can be applied [3]. Work of the inspection is organized in the way that every inspector has a company car equipped with complete IT and technical equipment necessary for implementation of inspections on the road and in companies. Inspectors use objects where they live as workspace and the Ministry reimburses part of the costs. Activities of the inspectors are undertaken primarily on the basis of monthly work plan and petitions are submitted electronically (e-mail or via central information system). Inspectors have to submit to their superiors updated daily, weekly and monthly work reports and official offices where the superiors work are used for trainings and exchange of experience of the inspectors.

\subsection{The model of marginalization for road traffic inspection}

One of the models for restructuring of road traffic inspection is "marginalization", in a way that Directorate which deals exclusively with inspection activities has to be abolished and the road traffic inspection has to be 
established as independent service or department that would be an integral part of the Directorate for Road Traffic.

The model of marginalization implies and recognizes two very important things:

a) it is on the way of the rationalization, the subject of which is a long time topic and has been under discussion at the level of the state administration, and

b) merging of legislative and inspection activities within one administrative authority of the Ministry will be the basis for a stronger impact of the inspection on adoption of legislation, as well as for better exchange of information on situation in transport market between the legislative and inspection departments.

\subsection{The model of Agency for inspection of road transport}

One of possible solutions regarding the new organization of road traffic inspection is establishment of a special Agency for inspection in road transport, like in air and rail transport. Such agency already exists in the Republic of Croatia.

Establishment of a special Agency for inspection of road transport would have the following advantages:

a) possibility of funding the agency's work largely from fines and thus greater financial independence from the Ministry

b) greater independence in working activities

c) an independent organizational structure and management

d) larger area of jurisdiction in application of rules

e) greater freedom of planning activities.

Larger area of jurisdiction in application of the regulations should be viewed through expansion of power of control over:

a) driving schools and centers for training of professional drivers

b) stations for technical inspection of vehicles

c) other public authorities at various legal segments (eg. harmonization of timetables by the Croatian Chamber of Commerce, the issue of licenses by the State administration office, etc.).

Establishment of the Agency for inspection activities in road transport would be a formal separation of road traffic inspection from the Ministry and would reemphasize its importance for the functioning of transport market and road transport in general, and its impact on traffic safety, trends in transport field and cooperation with competent authorities in the European Community.

\section{Conclusion}

Impact of the road traffic inspection in all segments of transportation business and related activities in road transport is indisputable. It is a service that, in particular through monitoring of implementation of social legislation in road transport, is actively involved in regulation of transport market and enables equal competition on domestic and international market.

According to the presented mathematical model (model of specialization) it is calculated that the road traffic inspection (within Service for road traffic inspection) in the Republic of Croatia takes 53 inspectors. The authors believe, based on the analysis of possible advantages and disadvantages of road traffic inspection restructuring models presented and described in this paper, that the most suitable model for Croatia is actually a combination of the presented models, the model of specialization, regionalization, inspector's home labour and the establishment of the Agency for inspection in road transport. In such a way the positive effects of each model would be maximized, with a corresponding increase of efficiency and effectiveness in the road traffic inspection. For example, the inspector of road transport from Zadar, specializing in the control of transport legislation, would move from his home in the morning for occasional passengers transport inspection in the major tourist sites in the city. After the inspection, he would return home where he could arrange documents and report to the Head of the Regional Office for the central and southern Adriatic Sea in Split, who forwards the reports to his superiors in the Agency for inspection in road transport. The agency then collects all the results of the controls, makes certain conclusions and proposes measures to improve activities. The inspector from Zadar then repeats monitoring activities whenever there is a real need, with no bad impact on his private life and leisure time. In fact in such a way he would be fully work motivated.

\section{References}

[1] Civil Servants Act, Official Gazette 92/05. Available on www.nn.hr (17.06.2015)

[2] Banković, B. Organization and Technology of Public Passenger Transport. Faculty of Transport and Traffic Engineering, University of Belgrade, Belgrade, 1994.

[3] Model of road traffic inspectors "Working from home" Euro Controle Route (online). http://www.euro-controleroute.eu/site/en/ (01.05.2016)

[4] Handbook on procedures for road transport inspectors. An internal document of Directorate for transport inspection, Sector for inspection of road transport and road inspection, Services for road traffic inspection. Ministry of Maritime Affairs, Transport and Infrastructure Republic of Croatia, Zagreb, 2015.

[5] Regulation on the internal organization of the Ministry of Maritime Affairs, Transport and Infrastructure. Official Gazette 27/2012，36/2012 i 79/2013, available on www.nn.hr - an official part (search) and Ordinance on internal organization of MMATI (25.02.2015)

\section{Authors' addresses}

Saša Šolman, Ph.D.

Ministry of Maritime Affairs, Transport and Infrastructure Prisavlje 14, 10000 Zagreb, Croatia

E-mail: sasa.solman@mppi.hr

\section{Gordana Štefančić, Ph.D. Full Professor}

Veleučilište Hrvatsko zagorje Krapina (University of Applied Sciences),

Štalište hrvatskog preporoda 6, 49000 Krapina, Croatia

E-mail: gstefancic@fpz.hr

Marko Slavulj, Ph.D. Assistant Professor

Faculty of Transport and Traffic Sciences,

University of Zagreb,

Vukelićeva 4, 10000 Zagreb, Croatia

E-mail: mslavulj@fpz.hr 